purposes: competence paradigm: Mizhvuz. nauk.-prakt. konf. Kyiv: NAU [in Ukrainian].

Irfan Muzaffar, H.R. (2011). Designing Effective Introductory Teacher Education

Programs. USA: American Institutes for Research [In English].

MaryAnn Christison, F.L. (2015). A Handbook for Language Program Administrators.

USA: ALTA English Publishers [In English].

Organization, I.C. (2009). Doc ICAO 323 Guidelines for Aviation English Training Programs. Montréal, Quebec, Canada: International Civil Aviation Organization [In English].

Organization, I.C. (2010). Doc 9835 Manual on the Implementation of ICAO Language Proficiency Requirements. Montréal, Quebec, Canada: International Civil Aviation Organization [In English].

Petrashchuk, O. (2017). Defining Competency and Excellence in Teaching Aviation English. The International Journal for ESP Practitioners, 03, 7-13 [In English].

Petrashchuk, O. (2016). Defining Competency Qualification of Aviation English Instructor.Warsow, Studi@ Naukowe: Changing Perspectives on Aviation English Training, 29: (2), 73-79 [In English].

УДК 378,004.9:378

DOI: https://doi.org/10.35387/od.1(19).2021.113-122

Султанова Лейла Юріївна доктор педагогічних наук, старший науковий співробітник, завідувач відділу теорії $i$ практики педагогічної освіти Iнституту педагогічної освіти $i$ освіти дорослих імені Івана Зязюна НАПН України
Sultanova Leila - Doctor of Pedagogical Sciences, Senior Researcher, Head of the Department of Theory and Practice of Pedagogical Education of the Ivan Ziaziun Institute of Pedagogical Education and Adult Education of the NAES of Ukraine

ORCID iD: http://orcid.org/0000-0002-3324-6926

E-mail: leilasultanova22.07@gmail.com

\title{
МОДЕЛЬ ФОРМУВАННЯ СУБ'ЄКТИВНОГО ОБРАЗУ ПРОФЕСІЙНОГО МАЙБУТНЬОГО СТУДЕНТІВ ГУМАНІТАРНОГО ПРОФІЛЮ У ЗАКЛАДАХ ВИЩОЇ ОСВІТИ
}

Анотація. У статті обгрунтовано модель фрормування суб'єктивного образу професійного майбутнього студентів гуманітарного профрілю. Представлено узагальнене визначення моделювання як методу науковго пізнання й визначено специфрічні особливості моделювання. Охарактеризовано етапи моделювання (постановка завдання; створення (вибір) моделі; дослідження моделі; перенесення знань про модель у знання про оригінал; перевірка істинності отриманих за допомогою моделі даних). Обгурнтовано логіку вибору структурно-фрункціональної моделі для дослідження процесу 
формування суб'єктивного образу професійного майбутнього студентів гуманітарного профрілю.

Описано методологічний, змістово-процесуальний та критеріально-діагностичний блоки структурно-фрункціональної моделі формування суб'єктивного образу профресійного майбутнього студентів гуманітарного профрілю. Методологічний блок передбачає обгрунтування психодидактичного, особистісного, аксіологічного, міждисциплінарного та компетентнісного методологічних підходів формування образу профресійного майбутнього, а також принципів діалогічності, особистісно-профресійної трансформації, перетворювальної взаємодії та життєвої творчої самодіяльності. Змістово-процесуальний блок передбачає визначення мети та завдань формування образу профресійного майбутнього; вибір фоорм і методів організації процесу формування образу проффесійного майбутнього. Критеріально-діагностувальний блок спрямований на розкриття основних складників образу професійного майбутнього (ціннісномотиваційного, когнітивного та операційного), на визначення критеріїв (система ціннісних орієнтацій студента, мотиваційний комплекс; теоретичні знання 3 питань фрормування образу профессійного майбутнього; практичні уміння та навички, необхідні для успішного формування образу профресійного майбутнього) та рівнів сформованості образу профресійного майбутнього (індиферентний, особистісноусвідомлюваний або ціннісно-значущий).

Ключові слова: метод наукового пізнання; модель; структурнофрункціональна модель; професійне майбутнє; студенти гуманітарного профрілю.

Sultanova Leila

\section{MODEL OF FORMATION OF THE HUMANITARIAN PROFILE STUDENTS' SUBJECTIVE IMAGE OF PROFESSIONAL FUTURE IN HIGHER EDUCATION INSTITUTIONS}

Abstract. The article substantiates the model of formation of the humanitarian profile students' subjective image of professional future. The generalized definition of modeling as a method of scientific knowledge is presented and the specific features of modeling are defined. The stages of modeling are described (problem statement; creation (selection) of a model; model research; transfer of knowledge about the model into knowledge about the original; verification of the truth of the data obtained with help of the model). The logic of choosing a structural-functional model for studying the process of formation of the subjective image of humanitarian profile students' professional future is substantiated. 
The methodological, content-procedural and criterion-diagnostic blocks of the structural-functional model of formation of subjective image of humanitarian profile students' professional future are described. The methodological block provides substantiation of psychology didactic, personal, axiological, inter disciplinary and competence methodological approaches to forming the image of the professional future, as well as the principles of dialogical, personal-professional transformation, transformative interaction and vital creative activity. The content-procedural block provides the definition of purpose and tasks of formation of the professional future image; the choice of forms and methods of organizing the process of forming the professional future image. The criterion-diagnostic block is aimed at revealing the main components of the professional future image - (value-motivational, cognitive and operational), to determine the criteria (the system of student's value orientations, motivational complex; theoretical knowledge on the formation of the professional future image; practical skills necessary for the successful formation of the professional future image) and levels of formation of the professional future image (indifferent, personally-conscious or value-significant).

Key words: method of scientific cognition; model; structurallyfunctional model; professional future; students of humanitarian profile.

Постановка проблеми, її актуальність. Обґрунтування моделі формування суб'єктивного образу професійного майбутнього студентів гуманітарного профілю є результатом виконання проєкту «Потенціал вищої освіти в умовах пандемії: глобальний, європейський, національний виміри» (реєстраційний номер: 2020.01/0172) Національного фонду досліджень України профрінансованого за кошти державного бюджету.

Для організації, вивчення та удосконалення процесу фрормування образу професійного майбутнього було обрано метод моделювання. Цілісність та системність процесу формування образу професійного майбутнього зумовлені наявністю взаємозв'язку елементів які $\epsilon$ його складниками. Саме цей закономірний зв'язок елементів і $€$ об'єктивною основою можливості моделювання.

Аналіз останніх досліджень і публікацій. Наукове обґрунтування методу моделювання представлено у працях Б. Глінського, Г. Корнєва, В. Штоффра (Глинский, Б., 1965; Корнев, Г., Непрокина, И., (1993); Штофрф, В., 1966) та ін. Наукове обґрунтування методу моделювання в педагогічних дослідженнях висвітлено в працях С. Архангельського, О. Дахіна, А. Зотова, Ю. Конаржевського, Д. Новикова, Л. Султанової, Ю. Шапрана (Архангельский, 1980; Дахин, 2003; Конаржевский, 1986; Новиков, 2001; Султанова, 2016, Шапран, 2015).

Питання самопроєктування як ефективного засобу саморозвитку особистості, досліджуються у наукових працях Т. Єрини, О. Іванової, І. Казакова, А. Маслоу, Г. Олпорта, О. Остапчук, К. Роджерса, та ін. (Ерина, 2009; Іванова, 2011; Казаков, 2011; Маслоу, 2003; Олпорт, 1998; Остапчук, 2009; Роджерс, 2002). 
Мета статті - обґрунтувати вибір методу моделювання у дослідженні процесу формування образу професійного майбутнього студентів гуманітарного профілю та охарактеризувати блоки моделі формування образу профресійного майбутнього студентів гуманітарного профрілю.

Виклад основного матеріалу дослідження. Узагальнено моделювання визначається як метод опосередкованого пізнання, при якому для отримання інформації про досліджуваний об'єкт, явище чи систему досліджується допоміжний абстрактний об'єкт або структура, які мають певну відповідність з реальними явищами і замінюють оригінали в отриманні узагальнених знань (Корнев, Непрокина, 1993).

Специфічними особливостями моделювання як методу $є$ цілісність вивчення процесу, що дозволяє побачити не тільки його складники, але й зв'язки між ними. Адже моделювання, як зазначає Е. Гусинський, передбачає розподіл («аналіз» - від грецького óvó́lvбıs - розподіл) реальної системи - оригіналу - на елементи, так чи інакше пов'язані між собою (Гусинский \& Турчанинова, 2003). Ще однією особливістю методу моделювання $є$ можливість вивчення процесу до його реалізації.

Процес моделювання вимагає наявності таких складників: суб'єкта, який з певною метою досліджує закономірності предметів або процесів природи, суспільства або мислення (дослідник); об'єкта дослідження (процес формування образу професійного майбутнього); моделі, яка опосередковано характеризує відношення між суб'єктом, який пізнає, і об'єктом, якого пізнають. Основною відмінною рисою моделювання як методу наукового пізнання $€$ те, що для дослідження об'єкта, який нас безпосередньо цікавить, використовується інший об'єкт (модель), що заміщає в цьому випадку перший.

Процес моделювання передбачає дотримання певної етапності або структури. У наукових публікаціях виділяють різну кількість етапів побудови моделі та по-різному називають ці етапи. Проте в цілому вона не має суттєвих відмінностей. Ми орієнтуємося на структуру процесу моделювання, запропоновану Б. Глінським (Глинский, Грязнов, Дынин, Никитин, 1965, с. 53-70).

Так, першим етапом процесу моделювання $є$ постановка завдання, розв'язання якого здійснюється за допомогою використання моделі. Завданням нашого дослідження $€$ сформування образу професійного майбутнього у студентів гуманітарного профрілю в умовах складної епідеміологічної ситуації. 3 метою реалізації поставленого завдання нами було вивчено особливості навчання студентів гуманітарного профрілю в умовах складної епідеміологічної ситуації. Реалізація поставленого нами завдання можлива за умови розроблення та впровадження моделі формування образу професійного майбутнього у студентів гуманітарного профілю. 
Наступний етап - створення (вибір) моделі. Вибір моделі, як зазначає Б. Глинський, може здійснюватися двома шляхами: на інтуїтивній та на логічній основі (Глинский, Грязнов, Дынин, Никитин, 1965, с. 55). Оскільки ми йдемо шляхом логічного вибору моделі - вважаємо за необхідне більш детально представити логіку вибору нами структурнофункціональної моделі. Моделювання може використовуватися з різною метою та на різних рівнях (етапах) дослідження. Тому існує велика кількість форм і видів моделей. Ми орієнтуємося на поділ моделей, представлений Б. Глинським, в основу якого покладено аналіз питання фрілософрії щодо використання процесу моделювання в науці. Так, автор пропонує класифрікувати моделі за такими типами: за способами їх реалізації (матеріальні - фрізичні моделі, математичні моделі; ідеальні моделі-уявлення, знакові моделі); за характером відтворюваних частин оригіналу (субстанціональні моделі; структурні моделі; функціональні моделі; змішані моделі); за способом реалізації: матеріальні та ідеальні. Мета такого розподілу - виявити природу моделі, з якою має справу дослідник, а далі й ті пізнавальні можливості моделі, які визначаються ії природою (Глинский, Грязнов, Дынин, Никитин, 1965, с. 71).

За характером відтворюваних частин оригіналу модель формування образу професійного майбутнього у студентів гуманітарного профрілю $є$ структурною і функціональною. Структурна вона тому, що імітує внутрішню організацію оригіналу. Оскільки структура - це спосіб внутрішньої організації елементів об'єкта, вона є однією з найсуттєвіших сторін будь-якої речі. Без розкриття структури неможливе пізнання внутрішньої природи, сутності об'єктів. Як відомо, структура може бути двох типів: структура певних відносно стійких речей та структура процесів. Відповідно до цього структурні моделі можуть бути статичні та динамічні (якою $є$ і наша модель). Функціональна вона тому, що імітує спосіб поведінки (функцію) оригіналу.

Використання структурно-функціональної моделі зумовлене двома причинами. Перша полягає в тому, що характер моделі залежить не тільки від характеру вихідної основи моделювання, але й від багатьох інших причин. Друга - полягає в тому, що більшість завдань дослідження мають комплексний, багатолінійний характер.

Третій етап процесу моделювання - дослідження моделі. На цьому етапі модель стає об'єктом дослідження. Усі дії спрямовуються безпосередньо на отримання знань про об'єкт, на встановлення законів його розвитку, його властивостей і відношень. Дослідження моделі стає, таким чином, опосередкованим вивченням нею модельованого об'єкта. Відмінності моделі від оригіналу можуть стати причиною появи закономірностей, які спотворюють справжній характер модельованого об'єкта. Звідси й виникає потреба вже в ході дослідження моделі зіставляти окремі результати з даними про оригінал. Ця потреба стає визначальною на наступному етапі моделювання - при перенесенні отриманих за допомогою моделювання даних на оригінал (Глинский, Грязнов, Дынин, Никитин, 1965, с. 62). У педагогіці однією з форм 
дослідження моделі як самостійного об'єкта є проведення експерименту, який передбачає розробку програми дослідження; практичну реалізацію розробленої програми; внесення коректив; уточнення покладеної в основу моделі гіпотези дослідження та створення остаточного варіанта моделі, готового до практичного втілення.

Четвертий етап - перенесення знань. Знання, отримані в процесі дослідження моделі, стосуються виключно об'єкта, який вивчається як модель. Однак нас цікавить не модель як така з їі властивостями, а властивості і відношення іншого об'єкта (оригіналу), який замінюється моделлю в процесі дослідження. Саме тому і виникає питання необхідності перенесення знань про модель у знання про оригінал.

Останній етап - перевірка істинності отриманих за допомогою моделі даних про модельований об'єкт і включення їх у систему знань про оригінал.

Таким чином, структура процесу моделювання, запропонована Б. Глинським, передбачає: актуалізацію вже накопичених про оригінал знань, зафіксованих в описі модельованого об'єкта, та констатацію неможливості безпосереднього вивчення об'єкта для отримання певних знань; вибір моделі; дослідження моделі; перенесення знань на оригінал; перевірка істинності отриманих даних.

Отже, процес формування образу професійного майбутнього у студентів гуманітарного профрілю $є$ цілісним і системним та передбачає наявність взаємопов'язаних елементів. Ця цілісність і системність зумовлені тим, що елементи, з яких складається процес, пов'язані один 3 одним певною закономірністю. Саме цей закономірний зв'язок елементів і $\epsilon$ об'єктивною основою можливості моделювання. Шляхом логічного вибору з усього різноманіття представлених типів моделей дослідження процесу формування образу професійного майбутнього у студентів гуманітарного профрілю нами було обрано структурно-функціональну модель.

Розроблена нами структурно-функціональна модель формування образу професійного майбутнього у студентів гуманітарного профілю $\epsilon$ сукупністю взаємопов'язаних блоків: методологічного, змістовопроцесуального та критеріально-діагностичного. Використання у дослідженні процесу формування образу професійного майбутнього у студентів гуманітарного профілю структурно-функціональної моделі дозволить дати відповідь на запитання про ефективність обґрунтованих нами структурних компонентів образу професійного майбутнього у досягненні ціннісно-значущого рівня сформованості образу професійного майбутнього.

Методологічний блок моделі. Методологічними регулятивами дослідження $є$ методологічні підходи формування образу професійного майбутнього: психодидактичний (дає можливість застосовувати знання психології розвитку та методики розвиваючого навчання у якості основи для побудови технологій формування образу професійного майбутнього шляхом інтеграції знань студентів з психології, дидактики, методів активізації навчально-пізнавальної діяльності); особистісний (визнає 
студента самосвідомим відповідальним суб'єктом власного розвитку), аксіологічний (дає можливість розглядати студента як особистість зі сформованою системою цінностей, якою він буде керуватися у своїх соціальних та професійних взаємодіях), міждисциплінарний (реалізовується шляхом включення в освітній процес системи знань 3 суміжних дисциплін) та компетентнісний (є однією з умов оновлення змісту вищої освіти й навчальних технологій, узгодження їх із сучасними потребами).

Принципами формування образу професійного майбутнього є: принцип діалогічності, особистісно-професійної трансформації, перетворювальної взаємодії; життєвої творчої самодіяльності.

Змістово-процесуальний блок моделі передбачає визначення мети формування образу професійного майбутнього та завдань, відповідно до яких обґрунтовано вибір форм і методів організації процесу формування образу професійного майбутнього. Так, доцільними формами організації процесу формування образу професійного майбутнього $є$ : навчальні заняття; самостійна робота; контрольні заходи тощо. Серед ефективних інтерактивних форм варто виокремити: проектноінформаційний семінар, тренінг, неформальні зустрічі (Bar Camp) тощо.

3 метою досягнення студентами ціннісно-значущого рівня сфрормованості образу професійного майбутнього передбачено використання найбільш ефективних, на наш погляд, методів і прийомів організації освітнього процесу (метод кластерного аналізу, прийоми аналізу якості інформації та інші).

Також змістово-процесуальний блок передбачає розкриття змісту формування образу професійного майбутнього, спрямованого на розвиток складників професійного майбутнього, характеристику науковометодичного забезпечення процесу формування образу професійного майбутнього та визначення етапів його формування.

Критеріально-діагностувальний блок моделі формування образу профресійного майбутнього у студентів гуманітарного профілю спрямований на розкриття основних складників образу професійного майбутнього (ціннісно-мотиваційного, когнітивного та операційного), а також на визначення критеріїв образу професійного майбутнього (система ціннісних орієнтацій студента, мотиваційний комплекс; теоретичні знання з питань формування образу професійного майбутнього; практичні уміння та навички, необхідні для успішного фрормування образу професійного майбутнього). За цими критеріями визначається рівень сфрормованості образу професійного майбутнього (індифрерентний, особистісно-усвідомлюваний або ціннісно-значущий).

Таким чином, формування образу професійного майбутнього передбачає процедуру моделювання, яка дозволяє виявити закономірності цього процесу, перевірити істинність обґрунтованих нами теоретичних положень і дає можливість досягти практичного результату впровадження моделі, який полягає у досягненні студентами ціннісно-значущого рівня сфрормованості образу професійного майбутнього. 
Висновки і перспективи подальших досліджень. Отже, в якості методу наукового пізнання в дослідженні процесу фрормування образу професійного майбутнього у студентів гуманітарного профрілю було обрано метод моделювання.

Процес формування образу професійного майбутнього у студентів гуманітарного профілю є цілісним і системним та перебачає наявність взаємопов'язаних між собою елементів. Ця цілісність і системніть зумовлена тим, що елементи, з яких складається процес, пов'язані один 3 одним певною закономірністю. Саме цей закономірний зв'язок елементів і $\epsilon$ об'єктивною основою можливості моделювання.

Основною відмінною рисою моделювання як метода наукового пізнання $€$ використання моделі. Шляхом логічного вибору із усього різномаїття представлених типів моделей нами було обрано структурно-функціональну модель. Використання структурно-функціональної моделі фрормування образу професійного майбутнього у студентів гуманітарного профрілю дозволить дати відповідь на запитання про ефективність обгрунтованих нами ціннісномотиваційного, когнітивного та операційного складників образу професійного майбутнього.

Перспективним вбачаємо дослідження ефрективності структурно-функціональної моделі фрормування образу професійного майбутнього у студентів гуманітарного профілю шляхом впровадження в освітній процес закладу вищої освіти та розробку рекомендацій для викладачів закладів вищої освіти щодо ефективного формування образу професійного майбутнього студентів в умовах дестабілізації суспільства.

\section{Список використаних джерел}

Архангельский, С. (1980). Учебный процесс в высшей школе, его закономерные основы и методы. Москва: Высшая школа.

Глинский, Б., Грязнов, Б, Дынин, Б., Никитин, Е. (1965). Моделирование как метод научного исследования: гносеологический анализ. Минск: Изд-во МГУ.

Гусинский, Э., Турчанинова, Ю., (2003). Введение в фрилософию образования. Москва: Логос.

Дахин, А. (2003). Педагогическое моделирование: сущность, эфрфективность и ... неопределённость. Педагогика, 4, 21-26.

Ерина, Т. (2009). Педагогические условия обучения студентов вуза самопроектированию учебно-профессиональной деятельности: автореф. дис. ... канд. пед. наук. Белгород: БГУ.

Іванова, О. (2011). Самопроектування як невід'ємна складова самовдосконалення особистості. Педагогіка формування творчої особистості у вищій і загальноосвітній школі: зб. наук. пр. 21 (74), 74-78.

Казаков, И. (2011). «Самопроектирование»: анализ понятия. Вестник СГУТИКД, 2 (16).

URL.: http://www.vestnik.sutr.ru/joumals_n/1318571091.pdf. 
Конаржевский, Ю. (1986). Педагогический анализ учебновоспитательного процесса управления школою. Москва:

Педагогика.

Корнев, Г., Непрокина, И., (1993). Физические модели: методическое пособие для системы повышения квалифрикации учителей физики. Тольятти.

Маслоу, А. (2003). Мотивация и личность. 3-е изд. СПб.: Питер. 352.

Новиков, Д. (2001). Модели и механизмы управления развитием региональных образовательных систем (концептуальные положения). Москва: ИПУ РАН.

Олпорт, Г. (1998). Личность в психологии. Л.: ЮВЕНТА.

Остапчук, О. (2009). Самопроектування як засіб профресійної самореалізації майбутнього учителя. Наукові праці Донецького національного технічного університету. Серія: педагогіка, психологія i соціологія, 4(146). Донецьк: ДонHTY. URL.: http://ea.donntu.edu.ua/bitstream/123456789/16584/4/ostapchuk.pdf

Роджерс, К. (2002). Свобода учиться. М.: Смысл.

Султанова, Л. (2016). Обґрунтування вибору методу моделювання у дослідженні процесу розвитку полікультурної компетентності майбутніх викладачів. Витоки педагогічної майстерності, 17, 169174.

Шапран, Ю. (2015). Особенности моделирования профессиональной подготовки учительских кадров с позиций компетентностного подхода. Педагогика высшей школы, 1, 56-59.

Штофф, В. (1966). Моделирование и фрилософрия. М.-Л.: Наука.

\section{References (translated and transliterated)}

Arhangel'skij, S. (1980). Uchebnyj process $v$ vysshej shkole, ego zakonomernye osnovy i metody [The educational process in higher education, its legal foundations and methods]. Moskva: Vysshaja shkola [in Russian].

Glinskij, B., Grjaznov, B, Dynin, B., Nikitin, E. (1965). Modelirovanie kak metod nauchnogo issledovanija: gnoseologicheskij analiz [Modeling as a method of scientific research: epistemological analysis]. Minsk: Izd-vo MGU [in Russian].

Gusinskij, Je., Turchaninova, Ju., (2003). Vvedenie $v$ filosofiju obrazovanija [Introduction to the philosophy of education]. Moskva: Logos [in Russian].

Dahin, A. (2003). Pedagogicheskoe modelirovanie: sushnnost', jeffektivnost' i ... neopredeljonnost' [Educational modeling: essence, efficiency and ... uncertainty]. Pedagogika, 4, 21-26 [in Russian].

Erina, T. (2009). Pedagogicheskie uslovija obuchenija studentov vuza samoproektirovaniju uchebno-professional'noj dejatel'nosti [Pedagogical conditions for teaching university students to self-design educational and professional activities]: avtoref. dis. ... kand. ped. nauk. Belgorod: BGU [in Russian]. 
Ivanova, O. (2011). Samoproektuvannja jak nevid'jemna skladova samovdoskonalennja osobystosti [Self-design as an integral part of selfimprovement of personality]. Pedagogika formuvannya tvorchoyi osoby stosti u vy shhij i zagal'noosvitnij shkoli: zb. nauk. pr., 21 (74), 7478 [in Ukrainian].

Kazakov, I. (2011). «Samoproektirovanie» analiz ponjatija [«Self-design» analysis of the concept]. Vestnik SGUTiKD. 2 (16). URL.: http://www.vestnik.sutr.ru/joumals_n/1318571091.pdf [in Russian].

Konarzhevskij, Ju. (1986). Pedagogicheskij analiz uchebno-vospitatel'nogo processa upravlenija shkoloju [Pedagogical analysis of the educational process of school management]. Moskva: Pedagogika [in Russian].

Kornev, G., Neprokina, I., (1993). Fizicheskie modeli: metodicheskoe posobie dlja sistemy povyshenija kvalifikacii uchitelej fiziki [Physical models: a methodological guide for the system of advanced training of physics teachers]. Tol'jatti [in Russian].

Maslou, A. (2003). Motivacija i lichnost' [Motivation and personality]. 3-e izd. SPb.: Pite [in Russian].

Novikov, D. (2001). Modeli i mehanizmy upravlenija razvitiem regional'nyh obrazovatel'nyh sistem (konceptual'nye polozhenija) [Models and mechanisms for managing the development of regional educational systems (conceptual provisions)]. Moskva: IPU RAN [in Russian].

Olport, G. (1998). Lichnost' v psihologii [Personality in psychologists]. L.: JuVENTA. 345 p. [in Russian].

Ostapchuk, O. (2009). Samoproektuvannja jak zasib profesijnoi samorealizacii majbutn'ogo uchytelja [Self-design as a means of professional selfrealization of the future teacher].

Naukovi pratsi Donets'koho natsional'noho tekhnichnoho universytetu. Seriya: pedahohika, psykholohiya i sotsiolohiya - Scientific works of Donetsk National Technical University. Series: pedagogy, psychology and sociology, 4(146). Donets'k: DonNTU. URL.: http://ea.donntu.edu.ua/bitstream/123456789/16584/4/ostapchuk.pdf

Rodzhers, K. (2002). Svoboda uchit'sja [The freedom to learn]. M.: Smysl [in Russian].

Sultanova, L. (2016). Obgruntuvannia vyboru metodu modeliuvannia u doslidzhenni protsesu rozvytku polikulturnoi kompetentnosti maibutnikh vykladachiv [Substantiation of the choice of modeling method in the study of the process of development of multicultural competence of future teachers]. Vy'toky' pedagogichnoyi majsternosti - The sources of pedagogical skills, 17, 169-174 [in Ukrainian].

Shapran, Ju. (2015). Osobennosti modelirovanija professional'noj podgotovki uchitel'skih kadrov s pozicij kompetentnostnogo podhoda [Features of modeling professional training of teachers from the standpoint of a competence-based approach]. Pedagogika vysshej shkoly - Pedagogy of high school, 1, 56-59 [in Russian].

Shtoff, V. (1966). Modelirovanie i filosofija [Modeling and philosophy]. M.-L.: Nauka [in Russian]. 